\title{
GIS/RS-Based Flood Risk Mapping for the Eastern Honghu Flood Diversion Area*
}

\author{
Marco GEMMER \\ (Centre for International Development and Environmental Research and \\ Department of Geography, Justus Liebig University, Giessen, Germany)
}

\begin{abstract}
A first case study for the estimation of flood damages in the eastern Honghu flood diversion area is presented in this paper. The results display flood risk zones based on simulated estimation depths. They are the basis for an integrated model for flood damage estimation which combines a GIS-based hydrodynamic model for flood depth estimation with flow propagation and a GIS-, and RS-based unit flood damage model with different tangibles of flood damages. Hereby, the integrated flood damage estimation model proofs to be applicable at the Yangtze River.
\end{abstract}

Keywords: Honghu flood diversion area, flood inundation estimation, flood risk mapping

At present, great attention regarding flood protection is paid to the construction of the Three Gorges Project (TGP) at the Yangtze River. The TGP will definitively reduce the flood risk downstream of the dam but it is not the final solution for flood protection at the Yangtze River. The floods in 2002 have shown that the Yangtze tributaries contribute much to the flood risk at the Yangtze River. In addition, several flood events might occur until the dam will have full operational use for flood prevention in the year 2009.

Precipitation as the main reason for floods at the Yangtze River can be regarded as being underlying positive and negative trends ${ }^{[1]}$. Therefore, the magnitude of future flood events is unknown and cannot be estimated at present. Even if a hydrological forecast can be made, the elementary challenge is the handling of benefits and costs of flood protection measures. If the economic effects of floods are supposed to be minimised by flood control measures, the analysis of potential losses has to be enforced. Therefore, the potential risk within a flood diversion area or an embanked polder area, as part of structural flood protection in Hubei Province will be assessed in the current paper.

\section{Flood Hazards}

The morphological retention areas in between the river channel and the primary dykes at the

\footnotetext{
* Supported by the Key Laboratory of Hubei Provincial Waterlogged Disasters and Wetland Agriculture and the Key Project of Knowledge Creativity Engineering, CAS(KZCX3-SW-331) and National Natural Science Foundation of China (No. 40271112). Received:2003-08-01;Accepted:2003-11-23.Marco GEMMER, male, Born 1975, Ph.D. email: Marco.Gemmer@geogr.uni-giessen.de.
} 
Yangtze river had successively been reduced in the 20th Century to zero especially by building secondary dykes and claiming the retention areas ${ }^{[2-3]}$. Nowadays, the cultivated land stretches from the high banks directly to the channel and builds an area that could be described as a recent floodplain if there were no dykes ${ }^{[4]}$. Therefore, the cultivated land in the morphological floodplain can be regarded as high flood risk areas, even if overbank flood spill is not reached. It is impossible to permit the constructional use of these old settlement areas, but flood-prone areas should be distinguished as those, as it happens in Germany, by urban land use planning ${ }^{[5]}$.

The flood hazard probability will be reduced if pre-flood management provides adequate risk information for these areas e.g. flood risk zone maps and evacuation plans. An operational flood management system can minimise losses e.g. if evacuation plans are properly applied and all means of structural and non-structural flood protection are considered.

The Honghu flood diversion is a suitable area to apply an integrated model for flood risk mapping and deriving pre-flood management tools from this.

\section{The Honghu Flood Diversion Area}

The planning of fifty flood diversion areas with a flood capacity of $50 \times 10^{9} \mathrm{~m}^{3}$ along the middle reaches of the Yangtze River was decided in the $1950 \mathrm{~s}^{[6]}$. The polder construction was intended to be finished with the improvement of dykes and the construction of reservoirs at the Yangtze tributaries ${ }^{[7]}$. Additionally, reservoirs with a capacity of another $50 \times 10^{9} \mathrm{~m}^{3}$ were constructed in Hubei Province until today. They are supposed to mitigate flood waves from the tributaries, supply fresh water, and generate energy ${ }^{[8]}$.

However, the realisation of the official flood diversion plans was never accomplished. Polders like Jingjiang have been integrated in the planning and 24 polders in Hunan province have been constructed ${ }^{[2]}$. Others like the large Honghu flood diversion area have never been completed.

Honghu flood diversion area is the biggest of the designated retention areas. It is located between the mouth of Dongting Lake and Wuhan city at the northern bank of the Yangtze River in Hubei Province. The Honghu plain is part of the lowlands, which stretches from the northern Yangtze bank to the southern Hanjiang bank, namely the Jianghan plain.

The Jianghan plain is one of the most important bases for China's agricultural production but also a region where flooding and waterlogging occur frequently. This is due to the low-lying character of the area, which is characterised by deep alluvial deposits of the Yangtze River. The former floodplain of the Yangtze River is marked by numerous small rivers, artificial drainage and irrigation channels and shallow lakes, which were formed by the meandering Yangtze River and shallow groundwater. The waterways were formerly embanked by natural levees and overflowed those regularly and formed a depressed convex-shaped area of a typical wetland type. From the existence of the numerous lakes and waterways Hubei province got it's name "water bag".

Naturally, the Honghu plain as part of the Jianghan plain fulfilled the function of flood retention and flood regulation. After the 1954 flood event, the eastern embankment of the floodplain 
was established and the natural flood diversion capacity was lost. Based on a podium discussion between Hubei and Hunan provinces, the Honghu floodplain was designated as a flood diversion area.

The area of Honghu flood diversion district covers $2783 \mathrm{~km}^{2}$ with a floodwater capacity of $17.7 \times 10^{9} \mathrm{~m}^{3}{ }^{[9]}$. It contains $800 \mathrm{~km}^{2}$ mu cultivated land and is inhabited by 865000 people ${ }^{[10]}$.

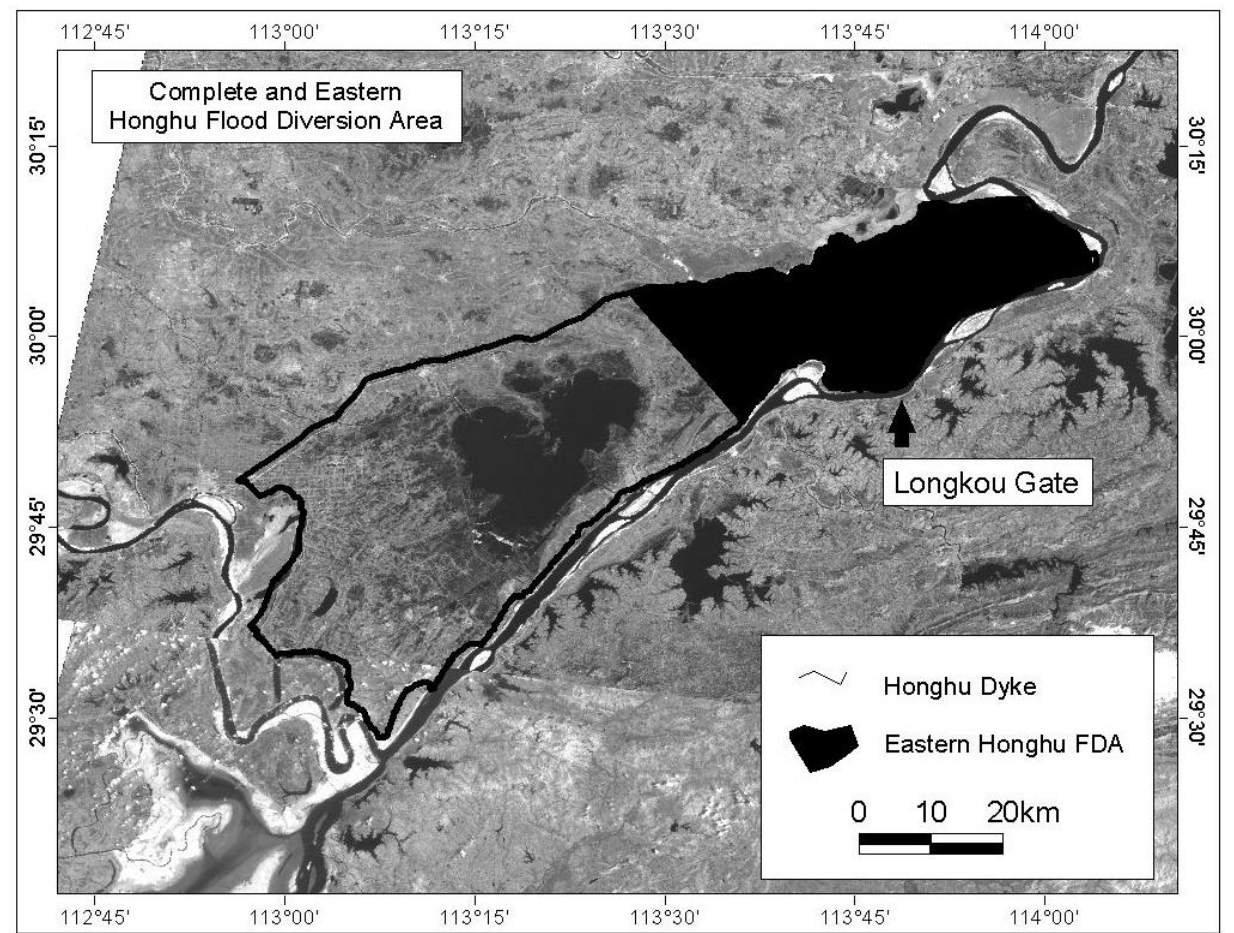

Fig. 1 Complete and Eastern Honghu Flood Diversion Area

In it's present form, Honghu flood diversion area cannot fulfil its designated role anymore ${ }^{\text {[2] }}$. If flood control in this area is supposed to be carried out, the polder has to be divided into several smaller parts. The actual planning of the Hubei Flood Control Office for the Honghu flood diversion area is proofing a division into three parts of which one would not be used for flood diversion anymore ${ }^{[11]}$. Therefore, flood risk mapping for the Honghu flood diversion area will be carried out for the eastern part of the polder area (Fig. 1). This is also advantageous since the size of the eastern part is about $830 \mathrm{~km}^{2}$. A comparison with other same sized flood diversion areas such as Jingjiang flood diversion with an area of $920 \mathrm{~km}^{2}$ will be feasible in further studies.

\section{Calculation of Flood Water Levels}

\subsection{Data Preparation}

The geo-spatial data for flood risk mapping are based on topographical maps, hydrological planning maps, and satellite images. They contain contextual and automatically acquired information. Contextual information on topography, waterways, administration, elevation, infrastruc- 
ture, and the geocoding of the satellite images are from 21 topographical maps ${ }^{[12]}$. They were scanned, geocoded, and digitised by the Chinese partner institute in Nanjing in autumn 2002. Furthermore, the LandsatTM 7/ETM image 123/39 (2000-02-16) was used for automatic data acquisition schemes. The LandsatTM images were geocoded using existing studies ${ }^{[2]}$ and based on the topographical maps for Honghu area.

The information on elevation (points and isolines) from the topographical maps were taken as thresholds for the calculation of a Digital Elevation Model (DEM). Isolines were transferred to points and, in addition to all other points from the maps, spatially interpolated by applying the Inverse Distance Weighted (IDW) interpolation method. The interpolated raster surface is based on a weighted average of the elevation points. The value of each cell is mostly influenced by nearby points and less by more distant points. The IDW method requires the specification of the power parameter and the search radius. The power parameter controls the significance of calculated station values upon the interpolated values. By defining a high power, more emphasis is placed on the nearest points, and the resulting surface will have more detail. The power parameter in the IDW interpolation was set to 6 . The choice of the relatively high power ensures a high degree of local influence and giving the output surface increased detail. The search radius has been specified by choosing a number of 4 neighbouring stations, i.e. the spatial interpolation has been carried out within a fixed radius of 4 neighbouring stations ${ }^{[13]}$.

The boundary layer for the eastern Honghu dyke was converted to a grid file and taken as a flow barrier for the analysis.

\subsection{Simulation of Flood Depths}

The input for the estimation of flood depths in eastern Honghu flood diversion area was given by a single cell inflow. A hydrograph data file hereby feeds the model with water. The hydrodynamic calculation is carried out by an ArcView extension from Heidelberg's Geomer Company. "The calculation of inundation areas is based upon a hydrodynamic approach. All eight neighbours of a raster cell are being considered. The discharge volume to the neighbouring cells is calculated using the Manning-Strickler formula. The gradient is defined by the difference between the lowest water level and the highest terrain elevation found in the cell and the neighbouring cells. This is done for each of the neighbouring cells. The width of the flow between cells is considered to be the same for all neighbours. For the diagonal neighbour cells the different length, though, is accounted for by the algorithm. The smallest iteration time step is adjusted dynamically. An important control criterion for this adjustment is the amount of water available. If the discharge rates become too large compared with the available volume, the iteration time step will be reduced. Only water level changes exceeding $1 \mathrm{~mm}$ are considered by that control mechanism. If the volumes exchanged between cells are very small, the algorithm will increase the iteration time step. This permanent optimisation keeps processing time at a minimum" [14].

The hydrograph represents a constant inflow of $10000 \mathrm{~m}^{3} / \mathrm{s}$ for four days and is aimed to proof the applicability of the model. The model output is inundation depth above surface area. The single cell inflow simulation was stared at Longkou flood diversion gate (Fig. 1). This gate is sup- 
posed to be opened for the use of Honghu flood diversion area.

Roughness values were specified to adapt the flow velocities to real world conditions. These values were derived from a satellite image based land use classification. The classes water (40), settlement (2), forest (6), non-irrigated land (20), and irrigated land (30) were classified (Manning values parenthesised). The Manning roughness values were given as $1 / n$ whereas $n$ is in units of $\mathrm{m}^{1 / 3} \mathrm{~s}$.

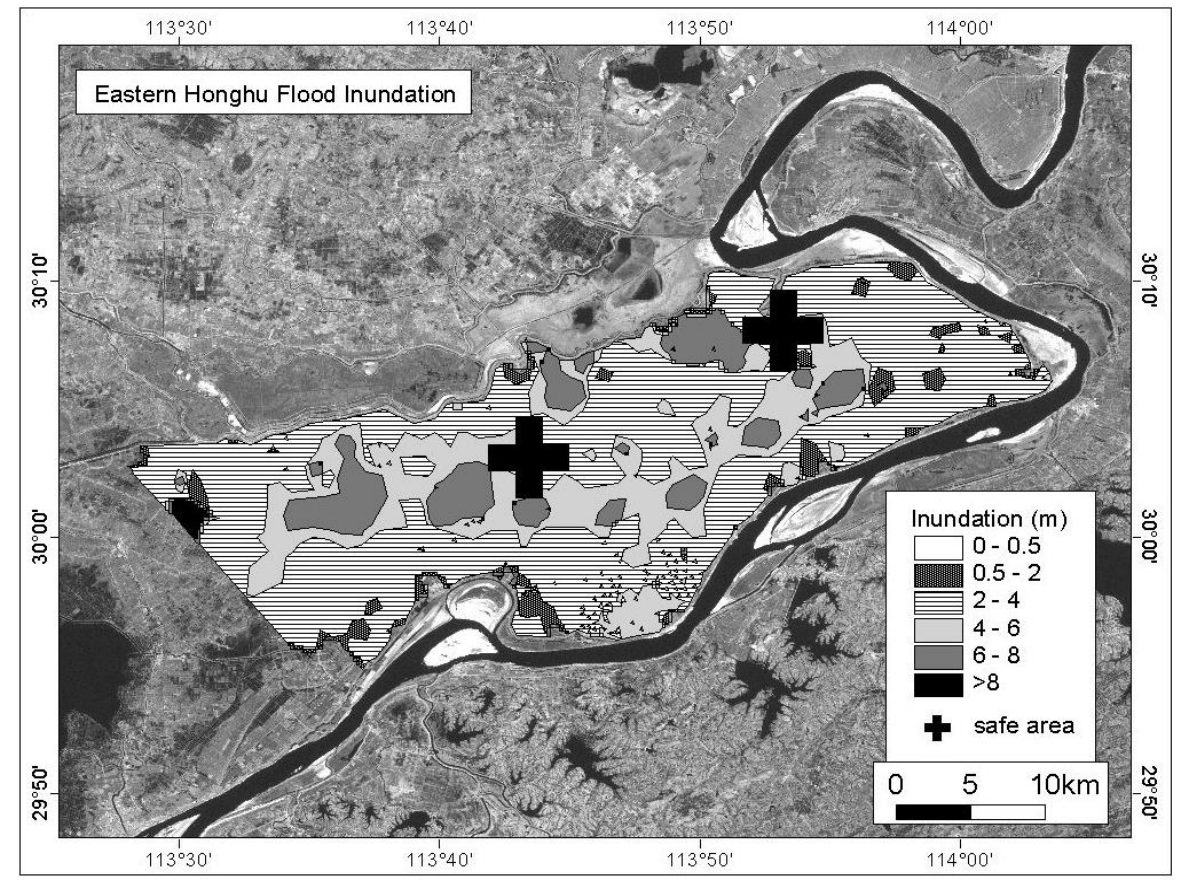

Fig. 2 Eastern Honghu Flood Inundation

Based on this simulation, the maximum inundation after four days is $12.5 \mathrm{~m}$. The inundation zones are displayed in Fig. 2. A zone with an inundation between 4 and 6 meters stretches through the central part of eastern Honghu flood diversion area. This is a former lake area of Jianghan plain and mainly covered by water bodies and rice paddies today. The most of eastern Honghu is inundated by $2-4 \mathrm{~m}$. This inundation is enough to destroy all values in the house's ground floors and to destroy the crop if the water is not drained within a few days. Other areas have not been covered by flooding water yet (highlighted in Fig. 2). They might be designed as safety areas in future evacuation maps. But inundation depths do not necessarily represent flood risk zones. They rather have to be estimated by also considering land use information. These data have just been acquired now. Since there has been no quality check, they cannot be applied in the present study yet.

If new economic data are available, the zhen-statistics and inundation values can be overlaid. By doing this, damage functions area created. Damage functions characterise the coherence between monetary flood losses based on land use classes and parameters of the floods such as in- 
undation depth or spatial and temporal distribution of the inundation. For the development of damage functions, it is indispensable to create a land use referenced damage.

\section{Outlook}

A first glance at the present results shows the severe situation of Honghu flood diversion area. The possibility of a high inundation enables a high flood diversion volume on the one hand but increases potential losses on the other hand due to an enormous velocity and complete overflowing of whole cities. The inundation will be even more disastrous in an upcoming flooding scenario since the 1998 hydrograph of Luoshan station will be taken in consideration. By applying this hydrograph to the Yangtze channel, more regard can be emphasised to the real channel conditions with rising and falling water depths. Nevertheless, the estimation of potential flood damage is essential for long-term flood prevention planning and emergency management. It will be the basis for flood risk maps and evacuation plans and can be applied to strengthen the people's awareness towards floods hazards, contribute to improve the safety of communities, and consequently make them more sustainable in a social and economic way. In a first step, the mitigation of flood damage and losses in the Honghu area depends on stocktaking of economic values and potential losses in flood-prone areas. This will be accomplished when new economy statistics are available. Nevertheless, forms of damages are very diverse, e.g. through to water pressure, upwelling, wash of waves, erosion, avulsion, siltation and accumulation, short-circuits, etc. They can not be assessed due to the comparatively big size of the flood diversion areas. The estimation of potential losses by applying hydrodynamic models and statistical data will therefore be the backbone of further studies which will also focus on the comparison of different flood diversion area. The economic costs of using Jingjiang and eastern Honghu flood diversion areas will then be assessed in a cost-benefit analysis whereas the benefit will be illustrated in a decrease of the water level in the main channel due the application of the flood diversion manoeuvre.

Acknowledgement Thanks must be given to Jiang Tong (Nanjing Institute of Geography and Limnology, CAS) for his organisation of the filed trips and the acquisition of data. Ke Changqing (Department of Urban and Resource Sciences, Nanjing University) was a great support translating Chinese statistics. Zhao Minzheng and Wang Jun (Hubei Province Flood Control Office) provided valuable information, materials, and discussions. Lorenz King (Department of Geography, JLU Giessen) supervised the research project.

\section{References}

Becker S, Gemmer M, Jiang T. 20th century precipitation trends in the Yangtze River catchment. discussion papers 14. Center for International Development and Environmental Research, Giessen, 2003

Gemmer M. Hochwasserschutz und Landnutzungsaenderungen am Yangtze-Mittellauf, VR China. Satellitenbilddokumentierte Entwicklung der Metropole Wuhan und des Jingjiang-Hochwasserrueckhaltebeckens als Beispiel für die wachsende Bedeutung und limitierte Umsetzbarkeit einer bestehenden Hochwasserschutzplanung. Giessen: Department of Geography, Justus Liebig University, 2000 
3 King L, Gemmer M, Wang R. Hochwasserschutz und Landnutzung am Yangtze. Geographische Rundschau, 2001, 53 (10): 28-34

4 Federal Environmental Agency. Anforderungen des vorsorgenden Hochwasserschutzes an Raumordnung, Landes-/ Regionalplanung, Stadtplanung und die Umweltfachplanungen. Empfehlungen für die Weiterentwicklung. Umweltforschungsplan des Bundesministers für Umwelt, Naturschutz und Reaktorsicherheit. Forschungsbericht. 1998. UBA :296 16 140, Berlin, Texte: 45-99

5 Spanknebel G. Hochwasservorsorge - eine staatliche Aufgabe. Beitraege zum Hochwasser/Hochwasserschutz in Vergangenheit und Gegenwart. Erfurter Geographische Studien No. 9: Erfurt, 2000: 165-172

6 Hong Q Y. Zhongguo Jiang He Fang Hong Cong Shu, Changjiang Juan. Beijing: China Hydrological Power Publishing House, 1998

7 Jiang T. Analysis of flood hazards in the Yangtze River valley for sustainable flood risk management. dissertation thesis Justus Liebig University, Giessen. Shaker, Aachen, 2000

8 Gemmer M. Restrictions to the implementation of flood protection planning at the middle reaches of the Yangtze River. Flood Risks and Land Use Conflicts in the Yangtze Catchment, China, and at the Rhine River, Germany, Lang, Frankfurt, 2001: $177-180$

9 Hubei Sheng Fangxun Kanghan Zhihuibu Bangongshi. Hubei Sheng Fen Xu Hong Qu Tu Ce. Wuhan, 1994

10 Shui zi Yuan Ting. Zhongguo Da He Liuyu Shuiwen Ziliao. Shuizi Yuan Ting. Beijing, 1988

11 Hubei Flood Control Office. Planning for Honghu flood diversion area. Wuhan, 2001

12 China Survey Bureau. Topographical Maps 1:50,000, Beijing, 1980

13 Bill R. Grundlagen. der Geo-Informationssysteme. Vol. 2: Analysen Anwendungen und neue Entwicklungen. Heidelberg: Wichmann, 1999

14 Geomer M .Floodarea user manual. version 2.4, Heidelberg, 2002

\section{基于 GIS/RS 的洪湖东分洪区洪水风险制图 \\ Marco GEMMER \\ (Centre for International Development and Environmental Research and \\ Department of Geography, Justus Liebig University, Giessen, Germany)}

摘 要

本文计算了洪湖东分洪区洪灾损失. 洪水风险带以模拟的洪水淹没深度表示. 这是洪水风险综合评 价模型的基础. 本项研究基于 GIS 为基础的水动力模型计算洪水淹没深度;并以 GIS/RS 为基础建立了单 位洪水风险评价模型, 计算不同洪水风险带的直接损失. 研究表明, 综合洪水风险评价模型在长江流域应 用是可行的.

关键词 洪湖东分洪区 洪水淹没损失 洪水风险制图

分类号 $\mathrm{P} 338^{+} .9$ P283. 8 